\title{
PENGARUH PEMBERIAN EKSTRAK DAUN KELOR (MORINGA OLEIFERA LAM.) TERHADAP SEL KARDIOMIOSIT PADA TIKUS PUTIH (RATTUS NOVERGICUS STRAIN WISTAR) DENGAN DIET ATEROGENIK
}

\author{
Cindy Alverina ${ }^{1}$, Desy Andari ${ }^{2}$, Gita Sekar Prihanti ${ }^{3}$ \\ Fakultas Kedokteran, Universitas Muhammadiyah Malang, Jl. Bendungan Sutami 188 A Malang, \\ 65145
}

Email : cindy2206.ca@gmail.com

\begin{abstract}
ABSTRAK
Hiperkolesterolemia akan menyebabkan aterosklerosis yang menjadi faktor resiko yang kuat terhadap penyakit kardiovaskular yang ditandai dengan kerusakan kardiomiosit. Penyakit kardiovaskular menjadi salah satu penyebab kematian terbesar pada usia produktif. Ekstrak daun kelor (Moringa oleifera lam.) dengan kandungan vitamin C dan beta karoten diduga mencegah nekrosis kardiomiosit sehingga menurunkan resiko penyakit kardiovaskular. Penelitian ini bertujuan untuk mengetahui pengaruh ekstrak daun kelor (Moringa oleifera Lam.) terhadap sel kardiomiosit jantung pada tikus putih (Rattus novergicus strain wistar) dengan diet aterogenik. Penelitian ini menggunakan metode post test only control group design yang terbagi dalam 4 kelompok acak yaitu kelompok kontrol (diet aterogenik) dan 3 kelompok perlakuan (ekstrak daun kelor 200mg/ $\mathrm{KgBB}, 400 \mathrm{mg} / \mathrm{KgBB}$ dan $600 \mathrm{mg} / \mathrm{KgBB}$ ). Setiap kelompok terdiri 5 hewan coba dengan perlakuan selama 35 hari. Setiap kelompok dibuat preparat histologi jantung (pewarnaan HE) dan diamati dibawah mikroskop(400x) dengan bimbingan ahli patologi anatomi. Hasil uji one-way ANOVA menunjukkan terdapat perbedaan antar kelompok tikus $(\mathrm{p}<0,05)$. Hasil uji post hoc menunjukkan dosis $600 \mathrm{mg} / \mathrm{KgBB}$ yang paling signifikan dalam mencegah nekrosis kardiomiosit. Ekstrak daun kelor (Moringa oleifera lam.) berpengaruh sebesar 78,5\% terhadap jumlah nekrosis kardiomiosit, hal ini diduga disebabkan adanya kandungan vitamin $\mathrm{C}$, beta karoten, beta sitosterol, flavonoid dan polyphenol.
\end{abstract}

Kata Kunci : Ekstrak daun kelor, Diet Aterogenik, Nekrosis Kardiomiosit.

\begin{abstract}
Hypercholesterolemia cause atherosclerosis that would be risk factor of cardiovascular disease characterized by injured of cardiomyocytes. Cardiovascular disease one of the bigger mortality cause in productive age. Moringa leaf extract contains vitamin $C$ and beta carotene that might help to prevent cardiomyocytes necrosis so it can helps to decrease cardiovascular diseases risk. This experiment to determine the effects of Moringa leaf extract (Moringa oleifera lam.) to cardiomyocytes in white rats (Rattus novergicus strain wistar) with atherogenic diet. Using post test only control group design rats was divided into 4 groups randomly that was one control (atherogenic diet) and 3 treatment (moringa leaf extract with dose $200 \mathrm{mg} / \mathrm{kgBW}, 400 \mathrm{mg} / \mathrm{kgBW}$ and $600 \mathrm{mg} / \mathrm{kgBW}$ respectively) groups which consist of 5 rats and treated for 35 days. Histology preparation (HE staining) of each group was observed under a microscope (400x) with pathologist supervisor guidance. One way ANOVA showed there were a significantly difference among groups $(p<0,05)$. Post hoc test showed that moringa leaf extract in $600 \mathrm{mg} / \mathrm{KgBW}$ prevent the necrosis of cardiomyocytes most. Moringa leaf extract had an effect $78,5 \%$ to amount of cardiomyocyte necrosis, it likely caused by vitamin C, beta caroten, beta cytosterol, flavonoid and polyphenol contents.
\end{abstract}

Keyword: Moringa leaf extract, Atherogenic diet, Cardiomyocytes necrosis. 


\section{PENDAHULUAN}

Hiperkolesterolemia mengacu peningkatan kadar lipid dan kolesterol dalam darah yang menggambarkan manifestasi dari gangguan metabolisme lipoprotein. Lipoprotein yang paling tinggi kadar kolesterolnya adalah low density lipoprotein (LDL) yang apabila kadarnya di dalam serum tinggi menjadi faktor predisposisi terbentuknya ateroma. Hiperkolesterolemia akan menyebabkan aterosklerosis yang menjadi faktor resiko yang kuat terhadap penyakit kardiovaskular, seperti : penyakit jantung koroner, gagal jantung, hipertensi, infark miokard akut dan stroke (Price \& Wilson, 2013). Penyakit kardiovaskular menjadi salah satu penyebab kematian terbesar pada usia produktif. Di Indonesia penyakit kardivaskular terutama penyakit jantung kororner dan stroke menjadi perhatian karena kematian akibat kedua penyakit ini diperkirakan akan terus meningkat mencapai 23,3 juta pada tahun 2030. (KEMENKES RI. 2014)

Kadar kolesterol LDL yang tinggi merupakan penjejas utama endotel dan kardiomiosit. LDL akan mengalami oksidasi yang dipengaruh oleh protein dan/atau asam lemak menghasilkan LDL-oks. (Tomkin GH, \& Daphne O, 2012) Kemampuan LDL-oks dalam memulai terjadinya aterosklerosis menunjukkan bahwa LDLoks sangat mudah menimbulkan terbentuknya sel busa. Pada penelitian sebelumnya didapatkan pada kelompok dengan diet tinggi lemakterjadi perubahan gambaran histologi jantung yang ditandai dengan perubahan struktur kardiomiosit tidak beraturan yang merupakan tahap awal terjadinya nekrosis, dan hipertrofi yang ditandai adanya penebalan miosit ${ }^{[3,15]}$.Aisyah S, Balqis U, Friyan EK, $2014 \mathrm{Hal}$ tersebut karena inaktivasi nitric oxyde (NO) sehingga menyebabkan remodelling ventrikel dan terjadi hipertrofi akibat mempertahankan perfusi jaringan akibat beban jantung yang meningkat karena peningkatan tekanan darah. (Fantinelli JC, et al., 2012)

Penanganan awal terhadap risiko penyakit kardiovaskular telah berkontribusi secara bertahap terhadap kematian akibat penyakit jantung dan stroke. Berbagai pengobatan dilakukan untuk mengurangi risiko dan kematian akibat penyakit kardiovaskular. Terapi dengan obat kimiawi dan tradisional dapat dilakukan. Secara tradisional salah satunya dengan menggunakan ekstrak daun kelor (Moringa oleifera Lam.). Pohon kelor dapat tumbuh dengan baik di daerah beriklim panas sampai tropis seperti di Indonesia. Pohon kelor juga toleran terhadap curah hujan. Pembudidayaan pohon kelor juga mudah, dapat dilakukan pada skala rumah tangga, skala kebun maupun skala hutan tergantung kebutuhan. Semua bagian pohon kelor mengandung zat yang bermanfaat, tetapi kandungan terbanyak dapat ditemukan pada daun kelor.(Suwabyono U, 2008)

Daun kelor (Moringa oleifera Lam.) mengandung antioksidan antara lain alkaloids, saponin, fitosterols, tannins, fenolik, polyphenol dan flavonoid. Kadar Polyphenol dan flavonoid pada daun kelor diketahui lebih tinggi dibandingkan daun lain seperti daun labu silam dan daun pakis ${ }^{[19]}$. Daun kelor juga memiliki kandungan vitamin $\mathrm{C}$ $220 \mathrm{mg} / 100 \mathrm{~g}$ daun. Kandungan vitamin $\mathrm{C}$ daun kelor ini hampir 4 kali lebih banyak daripada daun lainnya seperti daun kenikir yang memiliki kandungan vitamin C 64,6mg/100g daun dan daun pepaya yang memiliki kandungan vitamin C 61,8mg/100mg daun ${ }^{[6,9]}$. Semua zat yang terkandung tersebut dapat mencegah LDL-oks. Berdasarkan penelitian sebelumnya diketahui bahwa ekstrak daun kelor (Moringa oleifera Lam.)dengan dosis $100 \mathrm{mg} / \mathrm{kgBB}$ dan $200 \mathrm{mg} / \mathrm{kgBB}$ dapat menurunkan kadar LDL (kolesterol jahat) dan meningkatkan kadar HDL (kolesterol baik).(Rajanandh MG, et al., 2012)

Berdasarkan fakta dan teori tersebut, maka dilakukan penelitian untuk mengetahui pengaruh pemberian terapi ekstrak daun kelor (Moringa oleifera Lam.) terhadap sel kardiomiosit jantung pada tikus putih (Rattus novergicus strain wistar)dengan diet aterogenik.

\section{METODE}

Kolesterol plasma terutama lipoprotein yang aterogenik yaitu LDL berperan khusus sebagai faktor risiko aterosklerosis. Secara patofisiologis aterosklerosis disebabkan karena disfungsi endotel dan inflamasi. Prosesnya diawali dengan berubahnya LDL menjadi LDL-oks akibat teroksidasi yang bersifat aterogenik. Dari sisi lain, kadar HDL yang tinggi dapat menurunkan risiko aterosklerosis karena menyebabkan transpor kolesterol nalik yang merupakan mekanisme protektif dari progresi aterosklerosis.(Adi PR, 2015) 
Aterosklerosis akan memicu peningkatan beban kerja jantung akibat mempertahankan perfusi jaringan. Hal ini dikarenakan aterosklerosis yang menyebabkan disfungsi endotel pembuluh darah. Peningkatan beban jantung ini yang menyebabkan jantung mengalami remodelling sebagai proses kompensasi/adaptasi. (Kowalak JP, et al., 2014) Selain itu, LDL-oks yang memicu munculnya sitokin proinflamasi kemudian akan menginduksi INOS (Inducible Nitric Oxyde Synthase) dalam miosit. Peningkatan jumlah NO pada jantung diketahui akan menyebabkan kerusakan miokardium.(Hussain SNA, et. al., 1997)

Jantung pada tikus secara makroskopis hampir sama dengan manusia. Bagian luar dapat dilihat terdapat apeks, basis dan aurikula pada kedua sisinya. Pada potongan longitudinal didapatkan pada jantung tikus terdiri dari 4 ruang yaitu 2 atrium dan 2 ventrikel (Treuting MP, et. al., 2012) Secara mikroskopis jantung tikus juga mirip dengan jantung manusia. Kardiomiosit pada jantung tikus terdiri sari serat-serat panjang, bercabang dan juga terdapat diskus interkalatus. Pada sekitar sel jantung ada selaput halus endomisium yang kaya akan pembuluh kapiler.(Velickov A,et. al 2013)

Berbagai penelitian tentang Moringa oleifera Lam pada beberapa tahun terakhir terutama pada tikus. Berdasarkan hasil penelitian in vitro pada hewan dan manusia membuktikan bahwa semua bagian dari Moringa oleifera Lam memiliki fungsi baik secara fisiologis maupun farmakologi. Penelitian sebelumnya yang dilakukan pada manusia mengindikasikan bahwa bubuk daun Moringa oleifera Lam yang diberikan secara oral diketahui berguna sebagai anti-hiperglikemia, anti dislipidemia, kemoprotektif, dan efek antioksidan tanpa menimbulkan efek samping.(Stohs SJ, \& Hartman MJ, 2015)

Analisis kualitatif terhadap ekstrak hidroalkoholik Moringa oleifera Lam membuktikan adanya kandungan â-sitosterol sebanyak 0,09\%. Kandungan â-sitosterol ini yang menurunkan kadar kolesterol dengan cara menurunkan konsentrasi LDL dalam plasma dan menghambat reabsorbsi kolesterol dari sumber endogen. Ekstrak Moringa oleifera Lam juga diketahui mengandung antioksidan flavonoids dan polyphenols. Senyawa ini secara signifikan dapat meningkatkan SOD dan katalase serta menurunkan kadar lipid peroksidase sehingga dapat menurunkan kadar kolesterol terutama LDL.(Rajanandh MG, et. al, 2012)
Superoksida adalah radikal bebas yang tidak stabil sehingga akan cepat mengalami dekomposisi membentuk oksigen dan hidrogen peroksidase. Tahapan reaksi jejas sel oleh radikal bebas adalah : 1. Inisiasi, permulaan terbentuknya radikal bebas; 2 . Propagasi, reaksi yang berkembang atas timbulnya radikal bebas berupa transfer atom atau penambahan atom; 3. Terminasi, pemusnahan atau inaktifasi radikal bebas baik oleh antioksidan endogen atau eksogen, maupun enzim superoksida dismutase.(Pringgoutomo S, et. al, 2006)

Tingginya kadar LDL dalam darah mengakibatkan molekul LDL teroksidasi dan terbentuknya lipid peroksida. Lipid peroksida merusak sel endotel pembuluh darah menyebabkan inflamasi dan menginisiasi munculnya sitokin proinflamasi seperti interleukin-1(IL-1). Dan TNFá. Sitokin proinflamasi tersebut menginduksi Inducible Nitric Oxide Synthase (INOS) dalam miosit dan endotel vaskular untuk memproduksi Nitric Oxide (NO). Pada penelitian sebelumnya diketahui bahwa jumlah NO yang diproduksi secara berlebih dalam jantung dapat menyebabkan terjadinya kerusakan miokardium. (Hussain SNA, et. al, 1997)

Hidroksil radikal merupakan hasil dari peroksidasi lipid dengan oksigen elektron tunggal yang berpotensi memiliki efek menghancurkan termasuk terhadap sel otot jantung. Jika tubuh tidak mampu untuk mengkompensasi jumlah SOR yang berlebihan dapat menyebabkan kematian sel. Kematian sel berupa nekrosis merupakan pola kematian sel yang utama. Jaringan nekrotik mengalami perubahan nuklear berupa basofilia kromatin memudar yang disebabkan aktifitas DNAase (kariolisis), melisutnya inti sel dan peningkatan basofil (piknosis), serta karioreksis yaitu fragmen inti sel yang piknotik:

Untuk mengendalikan dan mengurangi peroksidasi lipid, baik manusia dalam aktivitasnya menggunakan antioksidan. Antioksidan alami antara lain vitamin $\mathrm{E}$ yang larut lipid dan vitamin $\mathrm{C}$ yang larut air. Antioksidan terbagi menjadi dua kelas : 1. Antioksidan preventif yang mengurangi laju inisiasi reaksi berantai; 2. Antioksidan pemutus rantai yang mengganggu propagasi reaksi berantai inisiasi, propagasi dan terminasi (Botham KM \& Mayes PA, 2012) 


\section{METODE PENELITIAN}

Penelitian ini merupakan penelitian true experimental post test only control group design. Penelitian dilakukan di Laboratorium Biomedik Fakultas Kedokteran Universitas Muhammadiyah Malang dalam waktu 1 bulan mulai bulan Maret-April 2017. Populasi dalam penelitian ini adalah tikus putih (Rattus novergicus strain wistar). Sampel yang digunakan adalah tikus putih jantan (Rattus norvegicus wistar) umur 2 bulan, berat badan 150-200 gram dan dalam kondisi sehat yang ditandai dengan gerakan aktif serta memiliki mata yang jernih. Sampel dalam penelitian ini terdiri dari 4 kelompok.

Sampel diambil secara purposive sampling dari populasi tikus putih jantan (Rattus norvegicus wistar) sebagai hewan coba. Pada penelitian ini 28 ekor tikus masuk bersamaan pada proses adaptasi. Setelah proses adaptasi selesai, 28 ekor tikus dikelompokkan menjadi 4 kelompok, yaitu 1 kelompok kontrol (+) dan 3 kelompok dengan perlakuan. Dua ekor tikus cadangan dari masingmasing kelompok yang telah melewati masa adaptasi tetap diberi perlakuan, tapi tidak dibedah di akhir penelitian apabila tikus tiap kelompok tidak ada yang mati.

Alat yang digunakan untuk penelitian ini adalah : kandang pemeliharaan, kandang perlakuan, tempat makan dan minum, alat sonde lambung, gloves, alat bedah, papan bedah, timer, wadah organ. Bahan yang digunakan dalam penelitian ini sebagai berikut : tikus putih Rattus novergicus strain wistar, daun Kelor (Moringa oleifera Lam), pakan standart, pakan diet aterogenik, kloroform, formalin 10\%.

Pada penelitian ini hari 1-7 dilakukan proses adaptasi terhadap semua hewan coba. Kemudian pada hari ke-8 hewan coba dibagi menjadi 4 kelompok yaitu kelompok Kontrol positif, kelompok terapi ekstrak daun kelor $200 \mathrm{mg} / \mathrm{kgBB}$ , dosis $400 \mathrm{mg} / \mathrm{kgBB}$, dosis $600 \mathrm{mg} / \mathrm{kgBB}$. Kelompok kontrol positif diberi pakan standart, diet aterogenik dan minum aquades. Kelompok yang diberi terapi ekstrak daun kelor diberi pakan standart, diet aterogenik secara oral melalui sonde lambung dan minum aquades, kemudian diberi ekstrak daun kelor dengan dosis $200 \mathrm{mg} / \mathrm{kgBB}$, $400 \mathrm{mg} / \mathrm{kgBB}$ dan $600 \mathrm{mg} / \mathrm{kgBB}$ per sonde dua jam setelah pemberian diet aterogenik selama 28 hari. Kemudian pada hari ke-36 setiap tikus dianestesi dengan kloroform per-inhalasi, setelah itu dilakukan pembedahan untuk mengambil organ jantung tikus. Jantung tikus dibuat sediaan histologi kemudian di amati dibawah mikroskop(400x) untuk dihitung jumlah sel kardiomiosit yang nekrosis. Hasilnya dianalisis menggunakan One-way ANOVA, uji post hoc, dan uji regresi linier.

\section{HASIL PENELITIAN}

Pengamatan preparat untuk menghitung jumlah sel nekrosis pada jantung tikus dilakukan dengan menggunakan mikroskop cahaya melalui pembesaran 400x dengan bantuan supervisi yang menunjukkan adanya perbedaan jumlah sel nekrosis antar kelompok, seperti pada gambar 1 dibawah ini.

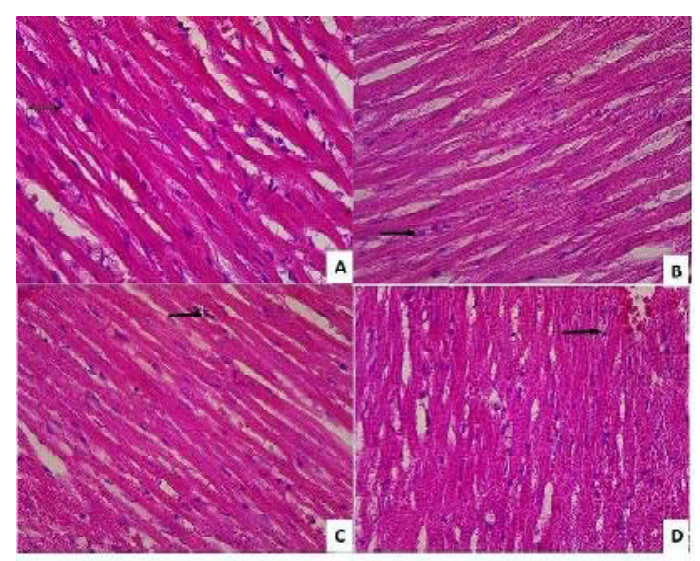

Gambar 1. Gambar mikroskopis otot jantung dengan pembesaran 400x.A=kelompok kontrol positif $\mathrm{B}=$ kelompok perlakuan 1 ( dosis ekstrak daun kelor $200 \mathrm{mg} / \mathrm{kgBB}$ ) C=kelompok perlakuan 2 (dosis ekstrak daun kelor $400 \mathrm{mg} / \mathrm{kgBB}$ ) $\mathrm{D}=$ kelompok perlakuan 3 (dosis ekstrak daun kelor $600 \mathrm{mg} / \mathrm{kgBB}$ ). Tanda panah (à) menunjukkan sel nekrosis.

Hasil pengukuran jumlah sel nekrosis pada jantung tikus ditunjukkan hasil pada tabel 1 Tabel 1. Hasil Pengukuran Jumlah Sel Nekrosis

\begin{tabular}{|c|c|c|c|c|c|c|c|}
\hline \multirow{2}{*}{$\begin{array}{l}\text { Kelo } \\
\text { mpok }\end{array}$} & \multicolumn{5}{|c|}{ Jumlah sel nekrosis } & \multirow{2}{*}{$\begin{array}{c}\text { Rata- } \\
\text { rata }\end{array}$} & \multirow{2}{*}{ SD } \\
\hline & 1 & 2 & 3 & 4 & 5 & & \\
\hline $\mathrm{K}(+)$ & 35 & 35 & 36 & 27 & 26 & 31,8 & $\begin{array}{c}4,8 \\
7\end{array}$ \\
\hline P1 & 20 & 26 & 24 & 23 & 25 & 23,6 & $\begin{array}{c}2,3 \\
0\end{array}$ \\
\hline P2 & 19 & 19 & 23 & 20 & 22 & 20,6 & $\begin{array}{c}1,8 \\
1\end{array}$ \\
\hline P3 & 17 & 15 & 16 & 11 & 17 & 15,2 & $\begin{array}{c}2,4 \\
8\end{array}$ \\
\hline
\end{tabular}

Semua data telah dilakukan uji normalitas (Shapiro-Wilk) dengan $\mathrm{p}=0,250$ dan uji 
homogenitas (Levene) dengan $\mathrm{p}=0,007$, maka didapatkan sebaran data normal dan varian data berbeda. Setelah dilakukan uji normalitas dan homogenitas kemudian dilanjutkan dengan uji Oneway Anova. Hasil analisis One-way Anova menunjukkan bahwa nilai $\mathrm{p}=0,000$ yang berarti terdapat perbedaan jumlah sel nekrosis yang bermakna pada tiap kelompok perlakuan.

Untuk membuktikan bahwa masingmasing data tersebut signifikan dilakukan dengan uji post hoc tambane dikarenakan hasil uji lavene menunjukkan varian data berbeda. Berikut ini adalah hasil dari uji Post Hoc Tambane.

Tabel 2. Hasil Uji Post Hoc Tamhane

\begin{tabular}{|c|c|c|c|c|}
\hline & $\mathbf{K}+$ & $\mathbf{P 1}$ & $\mathbf{P 2}$ & $\mathbf{P 3}$ \\
\hline+ & - & 0,090 & $\mathbf{0 , 0 2 7 *}$ & $\mathbf{0 , 0 0 3 *}$ \\
\hline $\mathbf{1}$ & 0,090 & - & 0,280 & $\mathbf{0 , 0 0 3 *}$ \\
\hline $\mathbf{2}$ & $\mathbf{0 , 0 2 7 *}$ & 0,280 & - & $\mathbf{0 , 0 0 3 *}$ \\
\hline $\mathbf{3}$ & $\mathbf{0 , 0 0 3 *}$ & $\mathbf{0 , 0 0 3 *}$ & $\mathbf{0 , 0 3} *$ & - \\
\hline
\end{tabular}

Berdasarkan tabel analisis uji Post hoc diatas dapat menjelaskan bahwa terdapat perbedaan penurunan jumlah sel nekrosis yang bermakna antara setiap kelompok perlakuan kecuali kontrol (+) dengan P1, dan P1 dengan P2.

Uji selanjutnya adalah uji regresi Linier dan hasilnya sebagai berikut:

Tabel 3. Hasil Uji Regresi Linier

\begin{tabular}{|c|c|c|c|c|}
$\mathrm{R}$ & $\mathrm{R}^{2}$ & $\mathrm{R}^{2}$ & Std. Error & $\begin{array}{c}\text { Durbin- } \\
\text { Wats on }\end{array}$ \\
\hline $0,892^{\mathrm{a}}$ & 0,796 & 0,785 & 3,14678 & 1,257
\end{tabular}

Uji regresi linear menunjukkan adanya pengaruh yang signifikan dari pemberian ekstrak daun kelor (Moringa oleifera lam.) terhadap jumlah sel nekrosis pada jantung tikus sebesar 78,5\% (Adjusted $\left.\mathrm{R}^{2}=0,785\right)$. Bentuk persamaan yang menghubungkan antara dosis daun kelor (Moringa oleifera lam.) dengan jumlah sel nekrosis adalah sebagai berikut :

$$
\begin{aligned}
& \mathrm{Y}=\mathrm{A}+\mathrm{B}(\mathrm{X}) \\
& \mathrm{Y}=30,720-0,026(\mathrm{X})
\end{aligned}
$$

Keterangan:

$$
\begin{aligned}
& \mathrm{Y}=\text { Jumlah sel nekrosis } \\
& \mathrm{A}=\mathrm{B} \text { pada konstanta } \\
& \mathrm{B}=\mathrm{B} \text { pada dosis }
\end{aligned}
$$

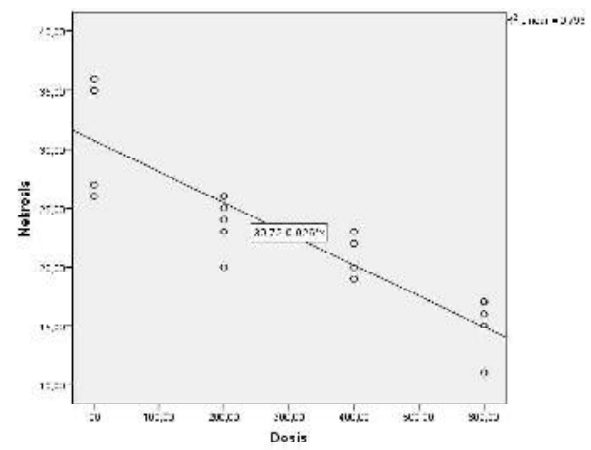

Gambar 2. Pengaruh pemberian ekstrak daun kelor terhadap jumlah nekrosis kardiomiosit

Berdasarkan grafik pada gambar 5.2 diatas tampak adanya pengaruh negatif antara pemberian ekstrak daun kelor (Moringa oleifera lam.) terhadap nekrosis sel kardiomiosit.Hal ini dapat diartikan bahwa tanpa mempertimbangkan pengaruh dari pemberian ekstrak daun kelor (Moringa oleifera lam.), maka rata-rata jumlah sel nekrosis pada kardiomiosit tikus akan cenderung tetap tinggi secara konstant 30,720 satuan (karena koefisien konstanta bernilai positif). Namun apabila mempertimbangkan pengaruh dari perlakuan dosis ekstrak daun kelor (Moringa oleifera lam.) akan menyebabkan perubahan jumlah sel nekrosis, dimana untuk setiap pemberian dosis $1 \mathrm{mg}$ akan menurunkan jumlah sel nekrosis tikus hingga 0,026 satuan.

\section{PEMBAHASAN}

Minyak jelantah yang diberikan secara oral bersifat toksin karena mengandung peroksida yang tinggi yang merupakan sumber radikal bebas. Apabila terpapar terus-menerus akan menyebabkan kerusakan jaringan pada jantung ${ }^{[3]}$. Hal ini sejalan dengan penelitian ini yang menunjukkan bahwa berdasarkan perhitungan jumlah kardiomiosit pada tiap kelompok tikus terdapat perbedaan yang bermakna. Hasil uji analisis One Way Anova pada penelitian ini adalah $\mathrm{p}<0,05$, hal ini menunjukkan bahwa terdapat perbedaan yang bermakna antar kelompok.

Mekanisme terbentuknya sel nekrosis akibat minyak jelantah seperti dijelaskan pada penelitian sebelumnya bahwa minyak jelantah mengandung radikal bebas dengan indikator peroksida $\left(\mathrm{COO}^{*}\right)$. Radikal bebas ini berikatan dengan $\mathrm{O}_{2}$ yang berada 
di dalam tubuh membentuk peroksil yang mengabsorbsi atm hidrogen dari molekul lipid tak jenuh. Hal ini menyebabkan reaksi yang menghasilkan peroksida seperti peroksinitrit yang bersifat lipofilik yang menyebabkan peroksida lipid dalam membran dan di dalam sel ini yang terserang adalah mitokondria. Sehingga mitokondria melepaskan ribosa dan retikulum endoplasmik dan menyebabkan pemasokan energi untuk memelihara fungsi dan struktur retikulum endoplasmik terlambat dan sintesis protein sangat menurun sehingga terjadilah kerusakan sel yang menyebabkan nekrosis. Terbukti pada penelitian ini sel otot jantung rusak yang ditunjukkan dengan inti sel yang mengkerut, gelap dan bentuknya tidak jelas.

Pada penelitian sebelumnya membuktikan bahwa daun kelor memiliki kandungan antioksidan diantaranya vitamin C, polyphenol, flavonoid dan karoten.(Agustina, 2016) Menurut Sandhiutami (2014) vitamin $\mathrm{C}$ merupakan antioksidan alami yang memiliki aktivitas antioksidan yang paling tinggi. Antioksidan berfungsi sebagai inhibitor untuk menghambat oksidasi dengan cara bereaksi dengan radikal bebas reaktif membentuk radikal bebas tak reaktif yang relatif stabil. Kandungan beta karoten pada ekstrak daun kelor juga melindungi membran lipid dari peroksidasi dan sekaligus menghentikan reaksi rantai dari radikal bebas. Ekstrak daun kelor juga mengandung beta sitosterol yang menurunkan kadar kolesterol dengan cara menurunkan konsentrasi LDL dalam plasma dan menghambat reabsorbsi kolesterol dari sumber endogen. Kandungan flavonoids dan polyphenols secara signifikan dapat meningkatkan SOD dan katalase serta menurunkan kadar lipid peroksidase sehingga dapat menurunkan kadar kolesterol terutama LDL.

Antioksidan dapat bekerja sebagai pemberi atom hidrogen terhadap radikal bebas dan mengubahnya menjadi bentuk yang stabil. Antioksidan juga dapat memperlambat laju autooksidasi sehingga kerusakan pada membran sel dapat berkurang. Salah satu mekanisme jantung dalam mengurangi radikal bebas adalah mekanisme scavenging oleh antioksidan. Penangkapan radikal bebas $\mathrm{O}_{2}^{-}$dan donasi hidrogen menghasilkan $\mathrm{H}_{2} \mathrm{O}_{2}$ yang merupakan senyawa yang stabil. Senyawa $\mathrm{H}_{2} \mathrm{O}_{2}$ ini berfungsi sebagai vasodilator sehingga menurunkan ritme sistem pembuluh darah sehingga beban jantung dapat berkurang. Hal ini sesuai dengan penelitian Natasya (2013) bahwa kandungan antioksidan dapat menjadi proteksi seluler bagi jantung sehingga dapat menurunkan kerusakan pada sel otot jantung salah satunya dapat menurunkan nekrosis sel pada otot jantung.

Pada uji post hoc tambane sebagai kelanjutan dari uji One Way Anova menunjukkan $\mathrm{p}<0,05$ sehingga terbukti bahwa pemberian ekstrak daun kelor mencegah peningkatan jumlah sel nekrosis pada otot jantung tikus putih. Perbedaan jumlah sel nekrosis signifikan dapat dilihat pada dosis $400 \mathrm{mg} /$ $\mathrm{KgBB}$ dan $600 \mathrm{mg} / \mathrm{KgBB}$ jika dibandingkan dengan $\mathrm{K}+$ akan didapatkan nilai $\mathrm{p}<0,05$ yang berarti kelompok perlakan tersebut datanya signifikan. Namun, pada dosis $200 \mathrm{mg} / \mathrm{KgBB}$ jika dibandingkan dengan kelompok $\mathrm{K}+$ didapatkan nilai $\mathrm{p}>0,05$ yang berarti tidak signifikan. Penelitian sebelumnya menunjukkan bahwa ekstrak daun kelor pada dosis $100 \mathrm{mg} / \mathrm{KgBB}$ dan $200 \mathrm{mg} / \mathrm{KgBB}$ dengan diet aterogenik sudah dapat menurunkan kadar lipid dalam darah yang merupakan pemicu terbentuknya nekrosis kardiomiosit. Hal ini dapat dikarenakan pada penelitian tersebut efek pemberian ekstrak daun kelor hanya dilihat dari kadar lipid dalam darah, sedangkan pada penelitian ini peneliti melihat efeknya pada organ jantung yang mana membutuhkan dosis yang lebih besar dan waktu yang lebih lama.

Hasil uji regresi linear menunjukkan adanya pengaruh pemberian ekstrak daun kelor (Moringa oleifera lam.) terhadap jumlah sel nekrosis pada jantung tikus sebesar 78,5\% (Adjusted $\left.\mathrm{R}^{2}=0,785\right)$.Sedangkan pada penelitian tentang pemberian ekstrak daun kelor dengan pelarut air terhadap kadar LDL dan HDL dengan diet aterogenik menunjukkan pengaruh menurunkan kadar LDL sebesar 35\% dan meningkatkan HDL sebesar 34,5\%. Hal ini disebabkan karena pada penelitian ini peneliti menggunakan ekstrak daun kelor dengan pelarut etanol $70 \%$. Pada penelitian Saputra (2013) menunjukkan bahwa penggunaan etanol 70\% berpengaruh lebih besar terhadap kadar antioksidan yang diperoleh. Hal tersebut yang menyebabkan pengaruh pemberian ekstrak daun kelor pada penelitian ini menunjukkan pengaruh yang lebih besar.

Kelemahan dari penelitian ini adalah adanya beberapa faktor yang tidak diteliti tapi memberikan pengaruh. Salah satunya adalah faktor genetik dari masing-masing tikus yang berbeda, sehingga hal ini dapat menjadi faktor perancu untuk penelitian. Selain itu juga terdapat faktor lainnya seperti metabolisme dan sifat dari tiap tikus. Metabolisme 
tikus yang berbeda menyebabkan responnya terhadap pemberian diet juga berbeda. Masingmasing tikus juga memiliki sifat berbeda seperti keinginan makan dan agresifitas. Keinginan makan masing-masing tikus berbeda hal ini juga dikarenakan pemberian pakan secara oral sehingga tidak dapat disamakan untuk semua tikus. Agresifitas tikus juga berbeda meskipun diet aterogenik diberikan lewat sonde tapi ada beberapa tikus yang sulit dan stres berlebih setelah pemberian diet lewat sonde. Hal-hal tersebut dapat menjadi faktor perancu dalam penelitian ini.

\section{KESIMPULAN}

Kesimpulan dari penelitian ini adalah : Ekstrak daun kelor (Moringa oleifera lam.) dapat mencegah nekrosis kardiomiosit pada jantung tikus putih strain wistar (Rattus norvegicus strain wistar) diet aterogenik, ekstrak daun kelor (Moringa oleifera lam.) mulai memberikan efek mencegah nekrosis kardiomiosit pada dosis $400 \mathrm{mg} / \mathrm{KgBB}$, ekstrak daun kelor (Moringa oleifera lam.) berpengaruh sebesar $78,5 \%$ terhadap jumlah nekrosis sel kardiomiosit.

\section{SARAN}

Saran untuk penelitian selanjutnya adalah : perlu adanya penelitian lebih lanjut tentang pengaruh pemberian ekstrak daun kelor (Moringa oleifera lam.) terhadap organ lain, perlu dilakukan penelitian tentang pemberian ekstrak daun kelor dengan metode ekstraksi berbeda, perlu dilakukan penelitian untuk mengetahui parameter antioksidan dari ekstrak daun kelor (Moringa oleifera Lam).

\section{DAFTAR PUSTAKA}

Adi PR, 2015, Pencegahan dan Penatalaksanaan Aterosklerosis, Dalam : Setiati S, Alwi I, Sudoyo AW, Simadibrata M, Setiyohadi B, Syam F, Buku Ajar Ilmu Penyakit Dalam, 6th edn, Jilid II, Interna Publishing, Jakarta, pp. 1427-1437.

Agustina, 2016, Aktivitas Antioksidan dan Organoleptik Kombucha Daun Kelor dengan Lama Fermentasi dan Konsentrasi Daun Kelor yang Berbeda, Universitas Muhammadiyah Surakarta, Surakarta, pp 15.
Aisyah S, Balqis U, Friyan EK, 2014, Histopatologi Jantung Tikus Putih (Rattus Norvegicus) Akibat Pemberian Minyak Jelantah, Jurnal Medika Veterinaria, Vol. 8, No. 1, pp. 87-90.

Alvarez MC, Candiz C, Fantinelli JC, Garciarena CD, Console GM,Chiape De Cingolani GE, Mosca SM, 2008, Is Cardiac Hypertrophy in Spontaneously Hypertensive Rats the Cause or the Consequence of Oxidative Stress?, National University of La Plata, Argentina, 31, pp. 1465-1476.

Anggraeni N, 2009, Pengaruh Lama Paparan Asap Knalpot dengan Kadar CO 1800 PPM terhadap Gambaran Histopatologi Jantung pada Tikus Wistar, JSC, 6, pp. 3-11.

Boshra V, Tajul AY, 2013, Papaya - An Innovative Raw Material for Food and Pharmacentical Processing Industry, Health and The Enviromental Journal, 4, Malaysia, pp. 6875.

Botham KM \& Mayes PA, 2012 Lipid yang Penting Secara Fisiologis, Dalam : Murray RK, Granner DK, Rodwell VW. Biokimia Harper, 27 edn, EGC, pp. 128-138 \& 239-240.

Cotran Ramzi S, 2007, Jejas, Adaptasi, dan Kematian Sel, In : Asroruddin M, Hartono $\mathrm{H}$, Darmaniah N, Buku Ajar Patologi, 7th edn, EGC, Jakarta, pp. 3-30.

Cheng SH, Barakatun-Nisak MY, Joseph A, Ismail A, 2015, Potential Medicinal Benefits Of Cosmos Caudatus (Ulam Raja): A Scoping Review, Wolters Kluwer, Malaysia, 20, pp. 1000-1006.

Daud Razali, 2007, Efek Suplementasi Vitamin E Terhadap Perubahan Histopatologis Jantung Mencit yang Diberi Ransum Lemak Tinggi, J.Ked.Hewan, 1, pp. 3-5.

Fantinelli JC, Caldiz C, Alvarez CM, Garciarena CD, Cingolani GDE, Mosca CM, 2012, Oxidative Damage in Cardiac Tissue from Normotensive and Spontaneously Hypertensive Rats: Effect of Ageing, University National de La Plata, Argentina, pp. 141-157.

Hussain SNA, Giaid A, El Dawiri Q, Sakkal D, Hattori R, Guo Yang, 1997, Expression of Nitric Oxide Synthases and GTP Cyclobydrolase I in the Ventilatory an Limb Muscle During Endotoxemia, American Journal of Respiatory Cell and Molecullar Biology, 17, pp. 173180. 
Kowalak JP, Welsh W, Meyer B, 2014, Buku Ajar Patofisiologi, EGC, Jakarta, pp. 138-180.

KEMENKES RI. 2014, Penanganan Penyakit Jantung, viewed 31 May 2015, < WWW.DEPKES.GO.ID/ARTICLE/VIEW/ $14112700011 /$ PENANGANAN-PENYAKITIANTUNG-HARUS-SESUAI-ILMU-KEDOKTERANTERKINI-DAN-MENGUTAMAKAN-KESELAMATANPASIEN.HTML $\geq$.

Natasya SO, Padaga CM, Wuragil DK, 2013, Ekspresi Inducible Nitric Oxide Synthase (INOS) dan Gambaran Histopatologi Jantung pada Hewan Model Tikus (Rattus norvegicus) Hiperkolesterolemia yang Diberi Terapi Yogurt Susu Kambing, Fakultas Kedokteran Hewan Universitas Brawijaya, pp. 1-11.

Price \& Wilson, 2013, Patofisiologi : Konsep Klinis Proses-Proses Penyakit, 6th edn, EGC, Jakarta, pp. 581-588.

Pringgoutomo S, Himawan S, Tjarta A, 2006, Buku Ajar Patologi I (Umum), 1st edn, Sagung Seto, Jakarta.

Rahayu, 2007, Studi Frekuensi Penggorengan dari Minyak Jelantah Bermerek dan Tidak Bermerek Terhadap Nekrosis Sel Hati, FKIP, UMM, Malang.

Rahmat H, 2009, Identifikasi Senyawa Flavonoid Pada Sayuran Indigenous Jawa Barat, Fakultas Teknologi Pertanian IPB, Bogor.

Rajanandh MG, Satishkumar MN, Elango K, Suresh B, 2012, Moringa oleifera Lam. A Herbal Medicine for Hyperlipidemia: A Pre-clinical Report, Department of Pharmacology, J.S.S University, India, pp. 790-795.

Romadhoni, D.A., Murwani, S., Oktavianie, D.A, 2012, Efek Pemberian Ekstrak Air Daun Kelor (Moringa oleifera lam.) Terhadap Kadar LDL danHDL Serum Tikus Putih (Rattus norvegicus) Strain Wistar Yang Diberi Diet Aterogenik, Fakultas Kedokteran Hewan Universitas Brawijaya, Malang.

Saputra I, Pribandini G, Zulaikah S, Rachimoelloh M, 2013, Ekstraksi Senyawa Bioaktiv Dari Daun Moringa Oleifera, Jurnal Teknik POMITS, Vol. 2, No. 1.

Suwahyono U, 2008, Khasiat Ajaib Si Pohon Gaib, Yogyakarta, Lily Publisher.

Sandhiutami NMD, Lestari R, Oktaviani T, Sari LY, 2014, Uji Aktivitas Antioksidan Rebusan Daun Sambang Getih (hemigraphis bicolor boerl.) Dan Sambang
Solok (aerva sanguinolenta (1.) Blume) Secara In Vitro, Universitas Pancasila, pp. 1-4.

Stohs SJ, \& Hartman MJ, 2015, Review of the Safety and Efficacy of Moringa Oleifer, viewed 31 May 2015, <http:// onlinelibrary.wiley.com/doi/10.1002/ ptr.5325/full>

Sumarno, Puspita T, Wahyuningsih R, 2007, Peran Antioksidan Pada Ekstrak Tepung Daun Kelor (Moringa oleifera lam.) Terhadap Kadar MDA Hepar Pada Tikus Rattus Novergicus Strain Wistar yang Dipapar Asap Rokok Akut,

Tomkin GH, \& Daphne O, 2012, LDL as a Cause of Atherosclerosis, Beacon Hospital and Trinity College Dublin 2, Ireland

Treuting MP, Ditnzis SM, Frevert CW, Liggitt D, Montine KS, 2012, Comparative Anatomy and Histology a Mouse and Human Atlas, Department of Comparative Medicine University of Washington School of Medicine Seattle, WA, USA, pp. 30-32.

Velickov A, Jancic N, Dinidic N, Rancic I, Bojanic N, Krstic M, 2013, Histological and Histochemical Characteristics of Rat Myocardium in Cadmium Toxicosis, Acta Medica Medianae, 52(2), pp. 15-22. 